\title{
The Islamic Intellectual Tradition in Persia
}

\author{
By Seyyed Hossein Nasr, edited by Mehdi Amin Razavi. Surrey: Curzon \\ Press, 1996, $375 \mathrm{pp}$.
}

The Islamic Intellectual Tradition in Persia is an edited collection of essays by Seyyed Hossein Nasr, the Iranian metaphysician and ontolgist, on Muslim philosophers and the intimate relationship between Persian culture and its philosophical schools. The 24 essays were written over a period of four decades and scattered among numerous journals and collections. The book is divided into six parts: Islamic thought and Persian culture; early Islamic philosophy; the works of al Suhrawărdi; philosophers, poets, and scientists; later Islamic philosophy; and Islamic thought in modem Iran. The essays highlight Nasr's prolific and leamed scholarship on the development of Islamic philosophy and illuminate many aspects of the rich philosophical traditions in Islamic Persia and its history.

Throughout this unique collection of articles, Nasr covers the lives and works of more than fifteen prominent thinkers and scientists who made significant contributions to the evolution of the Islamic intellectual traditions in the Muslim world in general and in Islamic Persia in particular. Among those covered are al Fărābī, Ibn Sīnā, al Birũnī, Nășir Khusraw, Fakhr al Dūn al Rāzī, al Suhrawārdī, Quṭb al Dīn Shirāzī, Șadr al Dīn Shirāzī, and Mullā Hādĩ Sabzawārī. Nasr presents their jdeas through their actual works and informs readers of their conditions and life stories in an easy and enjoyable style, which allows the reader to learn about their ideas and conditions through the lives of these great philosophers. Their lives and works cover a wide spectrum of the Muslim mind and bear a noticeable interplay of ideas from different fields, ideas that can neither be separated from their conditions nor confined to one field.

The book touches on many subjects of pure academic interest and provides an insight into Persian culture. Although the essays are useful in researching the intellectual history of Muslim philosophers in the largest sense, no one essay researches the development of specific ideas or aspects of the Persian philosophers. Nasr's essays describe al Farabī as the "second teacher" in philosophy and elaborates on Ibn Sīnā's contributions to logic and language, metaphysics and cosmology, medicine, pharmacology, and psychology. Some of their works cover classical debates on being and existence, what is learned and what is realized, discursive knowledge and the insights of illumination, and concepts of unity and 
diversity. Al Fārābī, Ibn Sīnā, and al Birūnī represented a generation of scientists, scholars, and philosophers with their profound views on the human being, God, and nature. $\mathrm{Al}$ Rāzì and Khusraw were poets and philosophers, and the former made many well-known contributions to classical religious debates, especially in the fields of theology and jurisprudence.

The book also covers the works of such other prominent thinkers as the poet 'Umar al Khayyām, the thoughts of Niẓāmī Ganjāwī, the extensive books of Afḍil al Dīn Kashanī, the trigonometry of Nāṣir al Dīn Țūsī, and the astronomy of Quṭb al Dīn Shirāzī. The influence of these men continued on future generations of scholars through both their books and the uninterrupted chain of learning circles.

Although Persian philosophical culture has absorbed many thoughts and concepts from the Orient, including that of Islam, the vast body of its philosophical and theological works is an integral part of the Islamic intellectual heritage, without which many chapters of the history of Islamic philosophy and science would remain obscure. Readers and researchers may find valuable similarities between the divine words of Islam and many aspects of thoughts and values found in other traditions or religions.

Nasr traces the universal thoughts of good and evil, as well as life and death, in Zoroastrian thought and compares them to their counterparts as found in the revealed message of Islam. Whether Zoroaster was one of the many thousands of prophets who preceded Muhammad or not, the fact remains that Zoroastrian traditions have shaped many aspects of post-Islamic Persian culture. Nasr traces cosmography and mysticism in pre-Islamic and Islamic Persia as an indication of the inevitable continuity of thought and philosophy in Persia. This comparative approach of tracing the cultural influences of Zoroastrianism on Persian philosophers may be extended to cover the influences of ancient Egypt, Babylon, Israel, India (both Hindu and Buddhist), and China.

In Islamic Persia, the terms and phrases used by Persian thinkers were mostly Qur'anic and were influenced strongly by Islamic concepts, among them hikmah, 'irfān, ishrāq, dhawq, and istidläl. Nasr argues that Persian has become an important intellectual language in Islam, despite the obvious asymmetry between Islamization and Arabization among non-Arab Muslims. The partial Arabization of Persia left room for the rise of modern Persian as an Islamic language, and eventually led to the emergence of a unified Islamic civilization with two cultural centers: one Arabic and one Persian. Later, as Persia became independent of the caliphate from the fourth hijri century onwards Persian began to develop rapidly in both poetry and prose, and from this early period scientific and philosophical works appeared in Persia. This laid the foundation of the more lucid and successful Persian philosophical texts of subsequent centuries.

Part Three, dedicated to al Suhrawārdī and his School of Ishrāq, also presents a detailed exposition on Sufism. The most important doctrinal aspects of Sufisim are articulated by both Muhiy al Dīn ibn 'Arabī and Shihāb al Dīn al Suhrawārdī, which were produced in the midst of controversial debates with theologians and advocates of rationalism in understanding the truth. Nasr describes in detail al Suhrawārdī's life, works, and sources of doctrines, as well as the meaning of ishrāq (illumination). The spread of this school did not occur during his lifetime (d. 1191) or during those of his few students and followers, but rather during the next century, when his ideas reached Arab, Turkish, and Persian scholars. Nasr has mapped the influence of al Suhrawārdī on Persian scholars and presented him as their real founding father. He also maps the rapid and profound integration of ishrāqi teachings into Shi'ism by Sayyid Haydar Amuli and Ibn Abi Jumhur, with the result that during later centuries most Ishrāqiis have been Shi'a theologians. In preSafavid days, such theologians included Mir Damad, Mulla Sadra, Sayyid Ahmad Alawi, Mulla Gilani, and Mulla Kashani. 
Al Suhrawārdī's original book, Hikmat al Ishrāq, was written in Arabic and later translated into Persian. The Ishrāqĩ school spread to India and Central Asia, but surprisingly did not reach far west of Persia. It would be of interest to reassess this school in view of the pre-Islamic thought of Persia. The ishrāqi wisdom of al Suhrawārdī itself contained many aspects of ancient Persian and Hermetic doctrines and teachings of earlier Sufis, especially the Gnostic doctrines of Ibn Arabī and the heritage of the Greek philosophers. As a necessary foundation, they contain some preparation in logic. However, instead of being bound to the plane of reason, they use this logic as a springboard for their flight into the heavens of gnosis.

One of the most interesting themes presented is the complex relationship between Sufism, Shi'ism, and Safavid dynastic politics. Many centuries after the fall of the Sassanid Empire, a Sufi brotherhood of Shaykh Șafiy al Dīn Aridibíli developed into an organized political force that one day would conquer Persia and weld it into a political unity for the first time. Starting as a Sufi order of Aridibili and continuing under the spiritual direction of a series of his descendants, the order grew strong in the politically disorganized Persia of the ninth hijrī century and, under Shāh Ismā'īl, defeated local rulers and unified Persia. Moreover, Persia was partly Shi'a and partly Sunni, but the Safavids adopted Shi'ism and elevated it to the empire's official school of thought.

The chain of sages after Nāșir al Dīn Țūsī suddenly had to address a large number of practical problems and found the environment conducive for developing their philosophy, theology, and jurisprudence. Isfahan became the new intellectual capital and absorbed newcomers from Lebanon, Bahrain, and other Persian cities. Nasr beautifully weaves together the diverse lines of Muslim intellectual activities in the east through the school of Isfahan. The city represents the post-Ibn Rushd era of Muslim intellectual activities, a time that is not covered in Western studies of Islamic philosophy. Nasr argues that this chain continued after Ibn Rushd and evolved into the many schools that have appeared during the past two centuries. He reviews the life and works of Mullā Hādi Sabziwārĩ of the thirteenth hijri century and the continuity of the chain thereafter. The book ends with a survey of the different philosophical schools in modern Iran, which includes the traditional religious centers, the Western institutions and university departments, and the few centers of mixed traditions and approaches.

In his review of Islamic thought in modern Iran, Nasr concludes that Islamic philosophy continues today as a living tradition in Persia and represents one of the most precious aspects of the intellectual heritage of Islamic philosophy at large. In his critique of the current state of Islamic philosophy, Nasr calls upon intellectual leaders to look toward Islam itself as the most important determining factor, and within it the intellectual heritage contained in the teaching of Islamic philosophy that can play a crucial role in preventing Muslims from committing intellectual suicide. He also calls upon scholars of Persia to learn from the works of others and make their own important contributions in collaboration with them, especially insofar as Western scholarship is concerned.

Throughout the book, it is clear that the language of Persia's Muslim philosophers was free from the technicalities of their Occidental counterparts. Nasr argues that Western philosophy gradually has lowered its aims until it has become a mere exercise of discursive reason on natural phenomena with a corresponding loss of meaning and value. Islamic philosophy, on the other hand, retained its divine connection and was saved from the destructive power of a mechanistical science in the hands of reductionist materialist formulations.

In general, the Muslim philosopher's approach to answering the classical eternal questions on life and its meanings do not limit themselves to the use of reason only; they also employ feelings and intuition. Persian philosophers showed their preference for the aesthetic or intuitional approach rather than rationalism, where words are used to get 
beyond words. Their works demonstrate that intellect is a faculty of higher intuition above and beyond reason and that it is the opposite of sensory intuition. Moreover, the lives of Muslim philosophers show that their vision was articulated into action and that their thought had a practical manifestation. Nasr argues strongly in favor of preserving the Islamic philosophical traditions and using them to confront the modern world and its materialistic approach. Only the rich inteilectual heritage of Isiam can provide the necessary weapons to combat the deadly influences of secularism and modernism. He argues that a new awareness and understanding of the nature of the Muslim's intellectual trad;tion is not just an academic interest; rather, it is one that involves their future existence, in the sense that for a nation to know where it wants to go it first must know where it is. This, in turn, is tied to a complete awareness of its intellectual past. However, the lack of extensive research in the particularities of Muslim intellectual traditions is denying Muslims access to their own hidden treasures.

The book is a valuable and unique addition to the small number of books written by Muslims on the evolution of their thought and werldview. In addition to all of the above interesting themes and arguments presented in the book, it is an important source with critical bibliographies that guide the interested reader to many other related subjects. The book is an excellent reference that offers both experts and laymen a wide selection of topics written in a simple language.

Laith Kubba

Political Analyst

London, UK 